\title{
KAJIAN OPTIMASI SKEMA PEMBANGKIT LISTRIK TENAGA MIKRO HYDRO RANTAU SULI di KABUPATEN MERANGIN, PROVINSI JAMBI
}

\author{
Adhe Indra Nurprayogo ${ }^{1}$, Widandi Soetopo ${ }^{2}$, dan Emma Yuliani ${ }^{2}$ \\ ${ }^{1}$ Direktur Teknis, PT. Karya Prima Cipta Usaha, Bali \\ ${ }^{2}$ Dosen Jurusan Teknik Pengairan, Fakultas Teknik, Universitas Brawijaya, Malang \\ Email : ${ }^{1}$ mankdhe@gmail.com, ${ }^{1}$ wid131835@yahoo.com, ${ }^{1}$ e_yuliani@ub.ac.id
}

\begin{abstract}
ABSTRAK: Dengan semakin menurunnya ketersediaan bahan bakar fosil maka perlu adanya energi alternatif pengganti yang baru dan terbarukan (Anonim, 2013).Pembangkit listrik tenaga air adalah salah satu alternatif energi yang relatif lebih stabil untuk memenuhi akan kebutuhan energi listrik. Dalam studi ini dilakukan optimasi terhadap skema PLTM Rantau Suli yang dilakukan dengan cara menentukan besar tinggi jatuh optimal, diameter pipa pembawa yang optimal dan pemilihan turbin yang tepat. Selain itu penentuan grafik flow duration curvejuga sangat berpengaruh kepada simulasi energi yang dihasilkan. Hasil dari studi ini didapatkan skema dengan tinggi jatuh 110,1 meter dan panjang pipa pembawa adalah 1957 meter merupakan skema terbaik, dengan grafik FDC dari pembangkitan metode F.J. Mocksehingga dapat menghasilkan energi listrik tahunan sebesar 11,92 GWHyang dibangkitkan menggunakan turbin Francis dengan nilai biaya energi yang terendah yaitu sebesar Rp. 532,3 per kwh. PLTM Rantau Suli direncanakan berumur selama 30 tahun yang memiliki IRR sebesar $14,46 \%$.
\end{abstract}

Kata kunci: PLTM, flow duration curve, energi listrik tahunan, turbin, biaya energi

\begin{abstract}
Renewable alternative energy is needed, because fossil fuels are decreasing (Anonymous, 2013). The hydroelectric power plant is one of stable alternatives energyto supply the demand for electrical. In this study, optimization of the Rantau Suli HEPP scheme is done by determining optimization of head, optimization of penstock diameter and the election of turbine. Moreover, the determination of flow duration curve graph is also very important to simulate the energy produced. The results of this study obtained schemes with head gross of 110.1 meters and the length of penstock is 1957 meters, and flow duration curve graphs from F.J Mock method is selected. So Rantau Suli HEPP can produce an annual electrical energy of 11.92 GWH a year which is generated using a Francis turbine with the lowest energy cost value of Rp. 532.3 per kwh. Rantau SuliHEPP is planned to be 30 years with IRR of $14.46 \%$.
\end{abstract}

Keywords: HEPP, flow duration curev, annual energy, turbine, energy cost

Ketersediaan dan harga dari sumber daya energi adalah salah satu kunci di dalam pertumbuhan dan perkembangan ekonomi pada negara berkembang.Dengan semakin menurunnya ketersediaan bahan bakar fosil maka perlu adanya energi alternatif pengganti yang baru dan terbarukan (Anonim, 2013).Indonesia di anugerahkan ketersediaan air yang melimpah.Sehingga potensial untuk pengembangan energi baru terbarukan. Tetapi hal ini belum sepenuhnya dimanfaatkan dengan maksimal untuk menggantikan energi fosil yang selama ini masih menjadi tumpuan untuk memenuhi kebutuhan akan energi (Pasalli and Rehiara, 2013). Pembangkit listrik tenaga air adalah salah satu alternatif energi yang lebih ramah akan lingkungan dan relatif lebih stabil untuk memenuhi akan kebutuhan energi listrik (Tanbhir, 2011).

Flow duration curve (FDC) atau kurva durasi aliran telah digunakan sejak sekitar 1915 (Younis and Hasan,2014). FDC adalah 
alat kunci untuk pengelolaan sumber daya air secara lestari.

Dalam kajian ini menitikberatkan pada kelayakan dari segi teknis dan segi ekonomis dalam mengoptimasi PLTMH Rantau Suli.Faktor - faktor yang berpengaruh dalam kajian ini adalah penentuan debit andalan sungai Batang Tembesi yang berpengaruh terhadap besarnya daya yang dihasilkan, penentuan diameter pipa pembawa (Deff) yang berpengaruh dalam perhitungan besarnya tinggi jatuh efektif (Heff), menentukan besarnya biaya investasi pembangunan pembangkit listrik tenaga mikrohidro dan biaya operasi dan pemeliharaan sebagai dasar penentuan kelayakan secara ekonomi.Dan kajian ini memfokuskan pada pengelolaan sumber daya air.

Tujuan dilakukanya kajian ini adalah untuk mengetahui hasil FDC sehingga dapat digunakan dalam pemilihan debit rencana, melakukan analisa tinggi jatuh dan diameter pipa pembawa sehingga didapatkan kehilangan tinggi yang terkecil, serta mengetahui turbin yang tepat untuk PLTM Rantau Suli, sehingga didapatkan energi yang optimal pada pembangunan PLTMH Rantau Suli dan pemanfaatan potensi sumber energi baru terbarukan dapat bekerja secara optimal dan berkelanjutan.
Manfaat dilakukanya kajian ini adalah dapat memberikan gambaran pemanfaatan kekayaan alam berupa air sungai sebagai sumber tenaga listrik untuk mengatasi krisis listrik di masyarakat pedesaan.

\section{METODE PENELITIAN \\ Lokasi Studi}

Pembangkit listrik tenaga mikrohidro (PLTMH ) Rantau Suli berada pada aliran Sungai Batang Tembesi yang terletak di Desa Rantau Suli, Kecamatan Jangkat Timur, Kabupaten Merangin, Provinsi Jambi. Secara geografis terdapat di Kabupaten Merangin (Anonim, 2015).

Lokasi bendung direncanakan sekitar 385 meter di atas air terjun Dukuh Betuah, berada di elevasi +946 meter dengan koordinat $2^{\circ}$ 33' 28.77' LS dan $101^{\circ}$ 58' 23.94" BT. Slope kemiringan sungai sekitar 3,85\%. Kondisi terberat di lapangan adalah banyaknya tebing tebing yang curam disekitar lokasi saluran pembawa.

Peta daerah tangkapan air PLTM Rantau suli memiliki luas sebesar $63,36 \mathrm{~km}^{2}$ seperti yang terlihat pada Gambar 1. Pembangkit listrik tenaga mikrohidro (PLTM) Rantau Suli direncanakan adalah tipe run-off river (RoR).

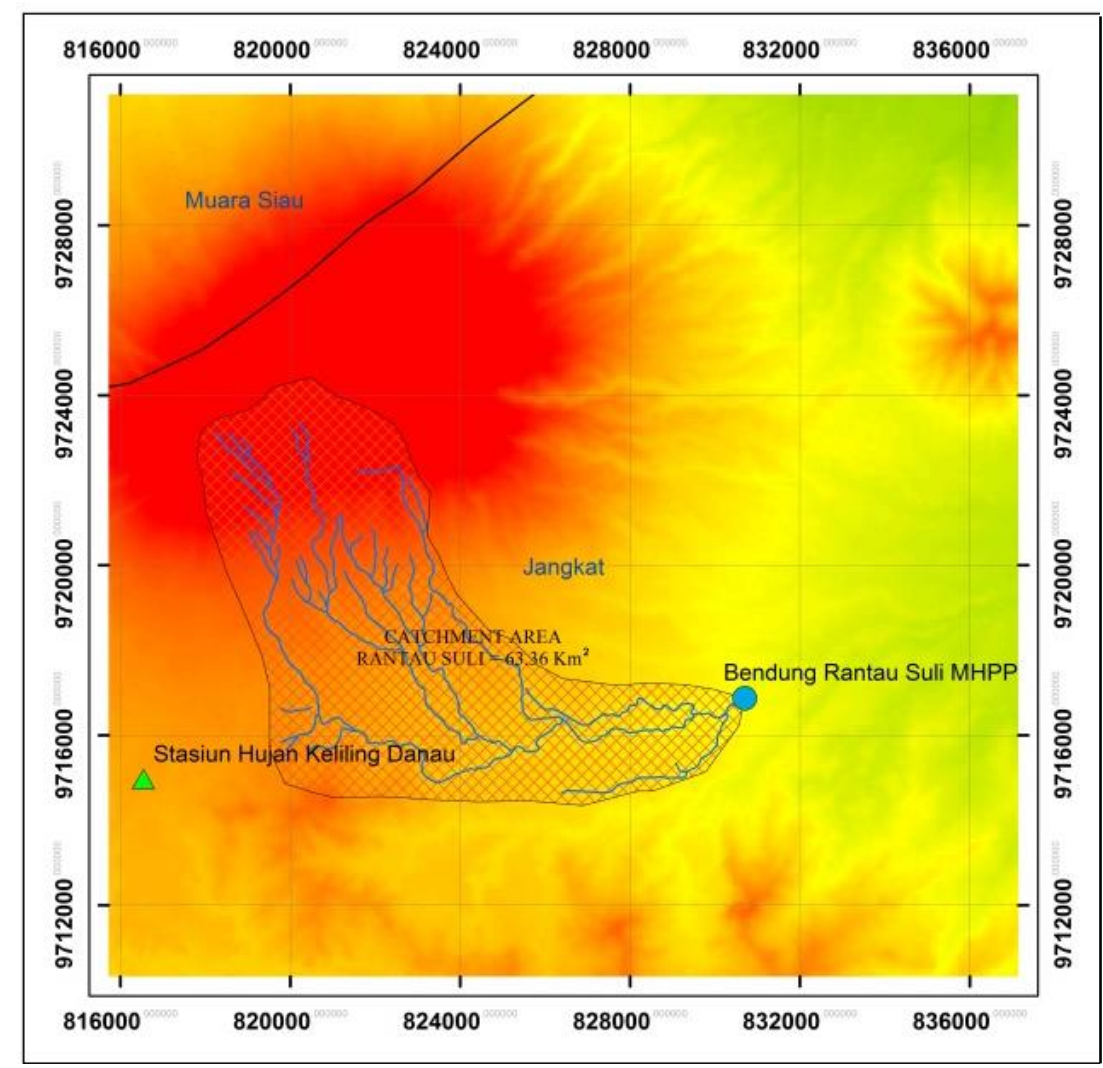

Gambar 1 Daerah Tangkapan Air 


\section{Diagram Alir Pengerjaan}

Tahapan pengerjaan studi ini dapat dilihat pada Gambar 2 sehingga tampak tahapan sehingga dapat menyelesaikan rumusan masalah pada studi ini.

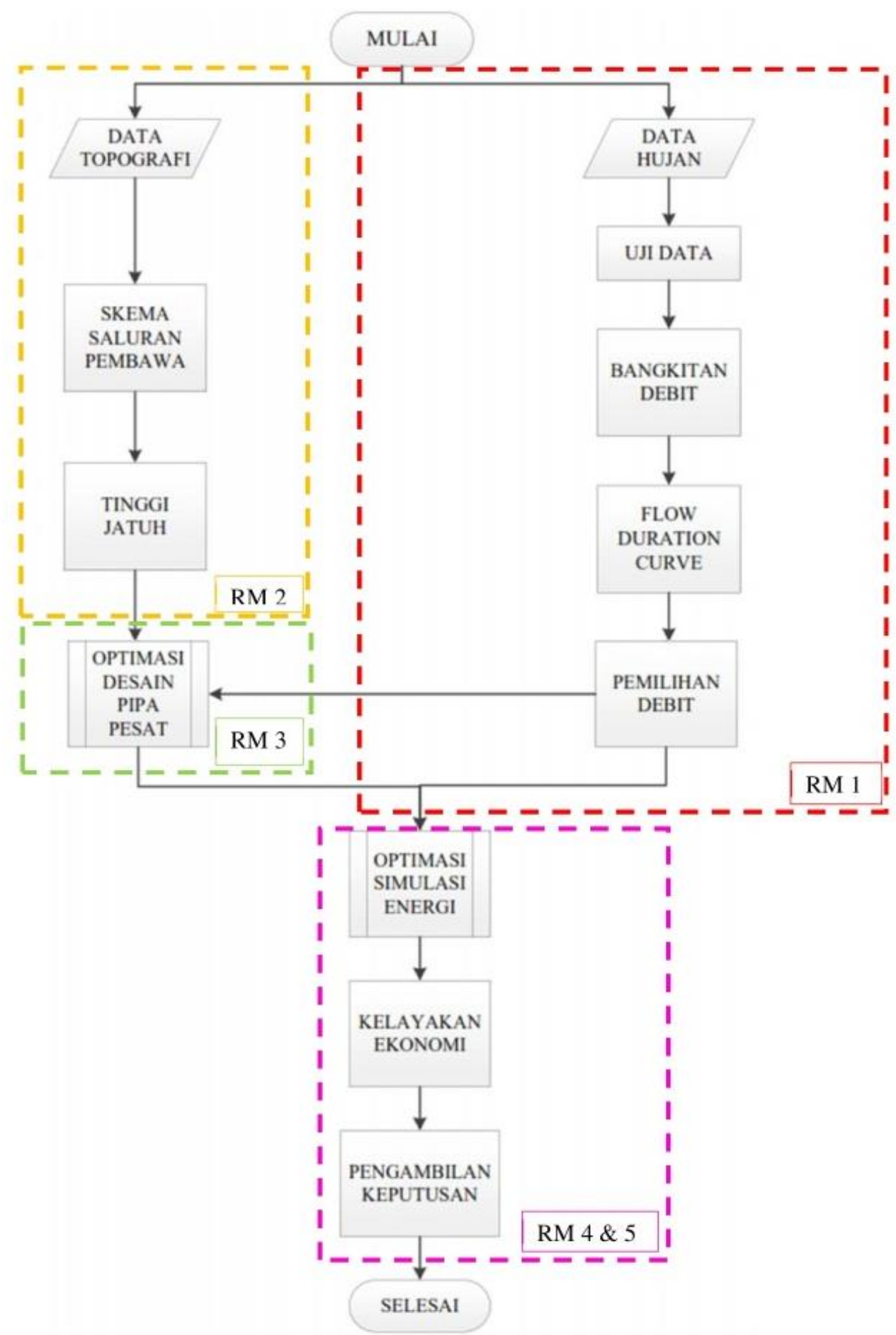

Gambar 2 Diagram Alir Pengerjaan

\section{Pengumpulan Data}

Dalam penyelesaian studi ini diperlukan data pendukung untuk menganalisis daerah studi. Data hujan diperoleh dari data stasiun hujan yang terdekat dengan daerah tangkapan air PLTM Rantau Suli yaitu stasiun hujan Keliling Danau pada koordinat $2^{\circ} 31^{\prime} 29.54$ " LS dan $100^{\circ} 55^{\prime} 20.44$ " BT. Keliling Danau dengan jumlah pencatatan selama 10 tahun dimulai pada tahun 2007 sampai dengan 2016. 


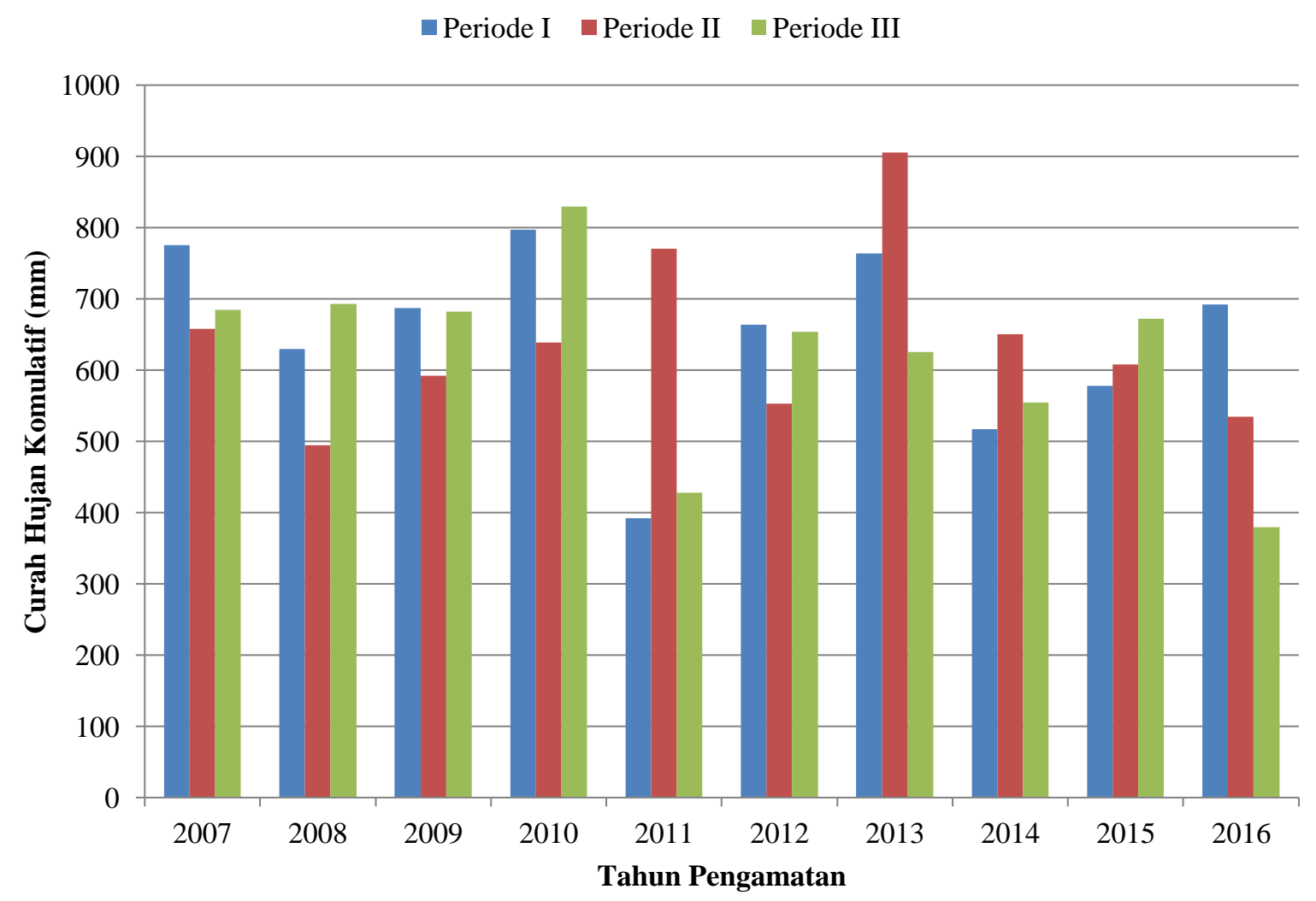

Gambar 3Diagram Curah Hujan Komulatif Setiap Periode Pengamatan

\section{HASIL DAN PEMBAHASAN}

\section{Analisis Hidrologi}

a) Melakukan uji kualitas data terhadap data curah hujan stasiun Keliling Danauantara lain uji konsistensi data dan uji outliers. Uji kualitas data tersebut dilakukan untuk memastikan data yang digunakan adalah data yang berkualitas, karena kualitas data sangat mempengaruhi hasil analisisnya;

b) Analisa bangkitan debit sangat diperlukan pada studi ini, dikarenakan keterbatasan data debit harian maupunbulanan di lapangan. Sehingga data debit perlu dibangkitkan dari data hujan 10 harian dengan menggunakan beberapa metode bangkitan debit, antara lain adalah metode F.J. Mock, metode NRECA, metode Tank Model, dan lain - lain. Pada studi kali ini dilakukan pembangkitan debit dengan metode F.J. Mock dan NRECA. Dikarenakan tidak ada data debit sebagai pembanding untuk kalibrasi maka dipakai koefisien runoff dari masing-masing metode sebagai kalibrasinya.

\section{Analisis Flow Duration Curve}

Analisa Flow duration curve sangat penting peranannya dalam studi atau kasus pengelolaan debit aliran rendah. Karena FDC dapat menyampaikan informasi yang komplek untuk para pembuat keputusan yang belum paham benar tentang hidrologi (Vogel and Fennessey, 1995). Pada studi ini dianalisa dua buah FDC yaitu FDC metode F.J. Mock dan FDC metode NRECA seperti pada

Gambar 4yang selanjutnya dilakukan analisa koefisien runoff sebagai dasar pemilihan debit dari metode mana yang akan dipilih. Dan contoh perhitungan koefisien runoff metode F.J. Mock adalah sebagai berikut :

1) $(1 \%-2 \%) * 3600 * 24 * 365 * 4,17 \mathrm{~m}^{3} / \mathrm{dt}$ $=1315790 \mathrm{~m}^{3}$ (volume air sungai pada probabilitas $1 \%-2 \%$ )

2) Jumlah semua volume sampai probabilitas terakhir sehingga didapatkan volume total untuk bangkitan metode F.J. Mock adalah $=69.242 .456,5 \mathrm{~m}^{3}$ 


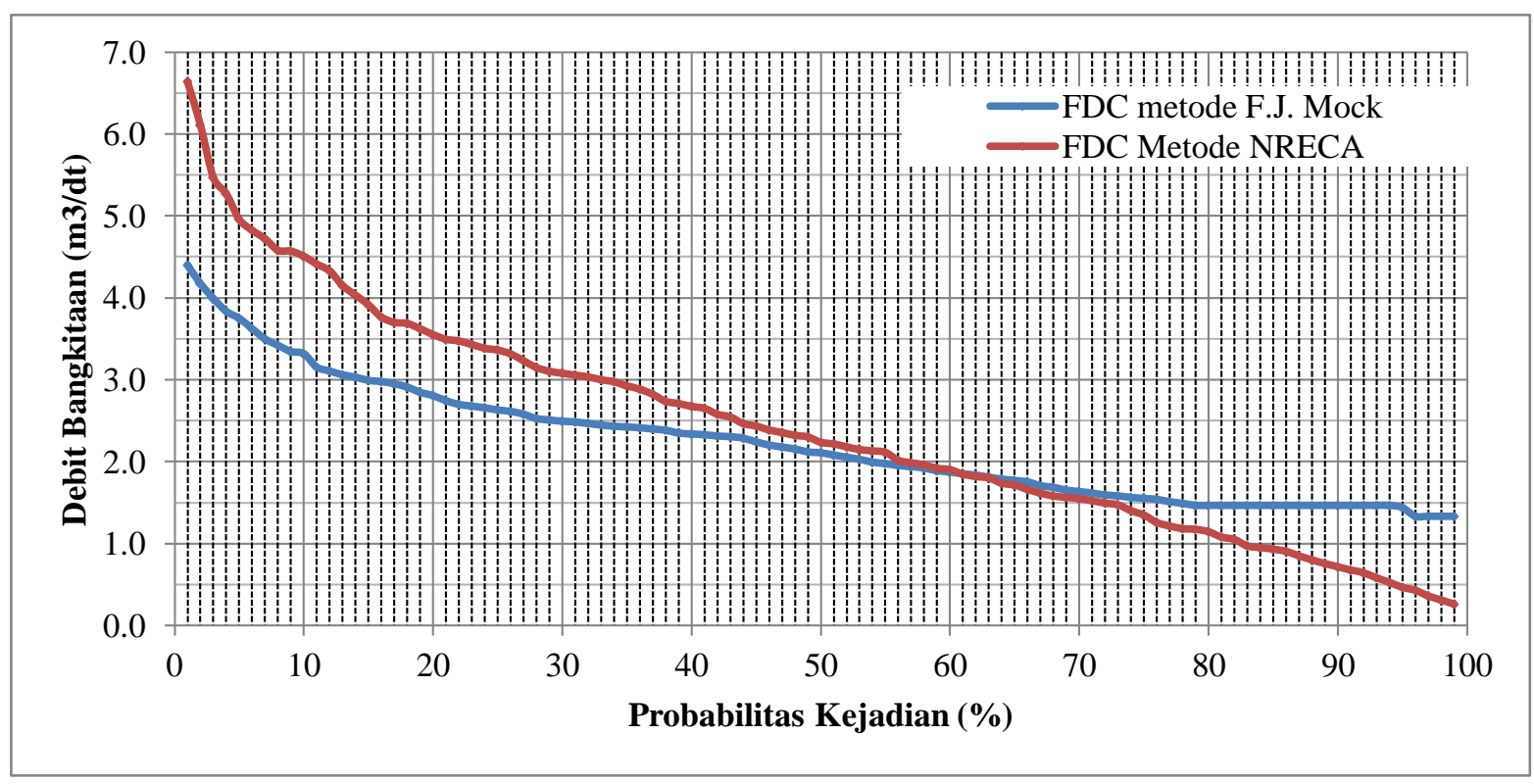

Gambar 4 Grafik Flow Duration Curve Dari Metode F.J. Mock dan NRECA

3) $69.242 .456,5 \mathrm{~m} 3 / 63,36 * 106$ (Luas DTA $)=1,092$ meter $=1092,84 \mathrm{~mm}$

4) Hujan rata-rata tahunan $=1911,07$ $\mathrm{mm}$

5) Sehingga koefisien runoff metode F.J. Mock $=1092,84 / 1911,07=0,57$

Sehingga dari perhitungan didapatkan koefisien runoff metode F.J. Mock adalah 0,57 sedangkan metode NRECA adalah 0,63. Maka dipilih koefien runoff yang terkecil yaitu koefisien runoffmetode F.J. Mock.

\section{Analisis Tinggi Jatuh}

a) Terdapat tiga skema yaitu skema 1dengan $\mathrm{Hg}=80,1$ meter dan panjang pipa pembawa $=1471$ meter, skema 2 dengan $\mathrm{Hg}=110,1$ meter dan panjang pipa pembawa $=1957$ meter, skema 3 dengan $\mathrm{Hg}=124,1$ meter dan panjang pipa pembawa $=2300$ meter ;

b) Menghitung kehilangan tinggi akibat saringan, pemasukan, gesekan, belokan, percabangan dan penyempitan.

c) Menghitung kehilangan tinggi akibat saringan, pemasukan, gesekan, belokan, percabangan dan penyempitan.

\section{Analisis Pukulan Air}

Pada perencanaan pipa pembawa perlu dilakukan analisa pukulan air (water hammer) yang berkaitan dengan desain ketebalan minimum yang diperlukan pipa untuk menahan besarnya pukulan air yang dialami oleh dinding pipa.

\section{Analisis Pukulan Air}

Pada perencanaan pipa pembawa perlu dilakukan analisa pukulan air (water hammer)yang berkaitan dengan desain ketebalan minimum yang diperlukan pipa untuk menahan besarnya pukulan air yang dialami oleh dinding pipa.

Analisis Ekonomis Diameter Pipa Pembawa

a) Menghitung biaya energi yang hilang setiap tahun;

b) Menghitungbiaya tahunan total pipa pembawa;

c) Mencari yang biaya yang terendah.

Contoh perhitungan untuk skema 1 debit

$\mathrm{Q}_{30}$ dapat dilihat pada

Tabel 2 dan grafik Gambar 5

\section{Analisis Pemilihan Turbin}

Dalam pemilihan turbin hal yang sangat berpengaruh adalah besarnya tinggi jatuh dan debit rencana. Setelah itu diplotkan kedalam grafik pemiliha turbin. Untuk perencanaan skema 1, 2, dan 3 termasuk dalam wilayah jenis turbin Horizontal Francis Turbine dan Turgo Impulse Turbine. Sehinga dipilihTurbin Francis karena harga jual relatif lebih murah dan memiliki tinggkat effisiensi lebih baik.

\section{Analisa Potensi Energi}

Pada studi ini diambil debit rencana antara debit $\mathrm{Q}_{30}$ sampai debit $\mathrm{Q}_{50}$.

Tabel 1 Debit Rencana 


\begin{tabular}{|c|c|}
\hline Probabilitas (\%) & Debit $\left(\mathrm{m}^{3} /\right.$ detik) \\
\hline 30 & 2,49 \\
\hline 35 & 2,42 \\
\hline 40 & 2,33 \\
\hline 45 & 2.24 \\
\hline 50 & 2,11 \\
\hline
\end{tabular}

Sumber: Hasil Perhitungan, 2018.

Menghitung bagaimana potensi energi dari ketiga skema pipa pembawa dengan berbagai macam debit rencana pada Pada studi ini diambil debit rencana antara debit $Q_{30}$ sampai debit $\mathrm{Q}_{50}$.

Tabel 1.

Setelah itu dilakukan simulasi energi tahunan untuk masing - masing skema dan di masing - masing debit rencana yang rekapitulasinya terlihat pada

Tabel 3. Pada
Tabel 3 terlihat bahwa dengan menggunakan debit rencana $\mathrm{Q}_{30}$ atau sebesar 2,49 $\mathrm{m}^{3} / \mathrm{dt}$ tidak layak secara teknis karena nilai faktor kapasitas berada dibawah $65 \%$ yang telah disyaratkan oleh PT. PLN (Anonim, 2017).

\section{Analisa Pengembangan Potensi Energi}

Setelah diketahui besarnya energi tahunan pada masing - masing skema dan skenario debit rencana, maka akan ditentukan skema dan skenario yang paling optimum dengan mencari biaya energi yang paling rendah.

Sehingga dariTabel 4, Tabel 5, dan Tabel 6, terlihat bahwa skema yang paling optimum adalah skema 2 dengan debit rencana Q50, diameter pipa pembawa 1,3 meter, dan energi terinstal $2 \times 0,95 \mathrm{MW}$ dengan turbin francis dan biaya energi sebesar Rp. 532,3.

Tabel 2 Diameter Ekonomis Pada Skema 1 (Debit Rencana 2,49 m³ detik)

\begin{tabular}{|c|c|c|c|c|c|c|c|c|c|}
\hline Debit & & Uraian & Satuan & $\mathrm{D} \min$ & \multicolumn{5}{|c|}{ Diameter Coba - coba } \\
\hline \multirow{9}{*}{$\begin{array}{l}2.49 \\
\mathrm{~m}^{3} / \mathrm{dt} \\
(\text { prob. } \\
30 \%)\end{array}$} & & Diameter pipa & $\mathrm{m}$ & 1.13 & 1.2 & 1.3 & 1.4 & 1.5 & 1.6 \\
\hline & $(1)$ & Kehilangan tinggi & $\mathrm{m}$ & 12.64 & 9.38 & 6.32 & 4.39 & 3.14 & 2.29 \\
\hline & $(2)$ & Head gross & $\mathrm{m}$ & 80.10 & 80.10 & 80.10 & 80.10 & 80.10 & 80.10 \\
\hline & (3) & Head nett & $\mathrm{m}$ & 67.46 & 70.72 & 73.78 & 75.71 & 76.96 & 77.81 \\
\hline & (4) & $\begin{array}{l}\text { Energi hilang } \\
\text { tahunan }\end{array}$ & GWh & 2.37 & 1.76 & 1.18 & 0.82 & 0.59 & 0.43 \\
\hline & $(5)$ & $\begin{array}{l}\text { Persentase head } \\
\text { loss }\end{array}$ & $\%$ & 15.77 & 11.71 & 7.89 & 5.48 & 3.92 & 2.87 \\
\hline & (6) & $\begin{array}{l}\text { Biaya energi } \\
\text { hilang tahunan }\end{array}$ & milyar & 2.37 & 1.76 & 1.18 & 0.82 & 0.59 & 0.43 \\
\hline & (7) & $\begin{array}{l}\text { Biaya pipa } \\
\text { tahunan } \\
(\mathrm{i}=10 \%, \mathrm{n}=30 \mathrm{thn})\end{array}$ & milyar & 1.97 & 2.09 & 2.27 & 2.44 & 2.61 & 2.79 \\
\hline & (8) & $\begin{array}{l}\text { Total biaya } \\
\text { tahunan }\end{array}$ & milyar & 4.34 & 3.85 & 3.45 & 3.26 & 3.20 & 3.22 \\
\hline \multicolumn{10}{|c|}{ Keterangan: } \\
\hline \multicolumn{3}{|c|}{ (1) Kehilangan Tinggi $=12.64 \mathrm{~m}$} & \multicolumn{7}{|c|}{ (5) per. Head $=((3)-(2)) /(3) * 100 \%=15.77 \%$} \\
\hline \multicolumn{3}{|c|}{ (2) Head Gross $=80.10 \mathrm{~m}$} & \multicolumn{7}{|c|}{ (6) Biaya energi $=(4) * 1000000 * 1000=$ Rp. 2.37 milyar } \\
\hline \multicolumn{3}{|c|}{ (3) Head nett $=(2)-(1)=67.46 \mathrm{~m}$} & \multicolumn{7}{|c|}{ (7) Biaya pipa $=414043.31 \mathrm{~kg} *$ Rp. $45000 * 0.10608=$ Rp. 1.97 milyar } \\
\hline \multicolumn{3}{|c|}{$\begin{array}{l}\text { (4) Energi hilang }=2.49 * 9.81 *((3)-(2)) \\
* 0.92 * 0.98 * 365 * 24=2.37 \mathrm{GWh}\end{array}$} & \multicolumn{7}{|c|}{ (8) Total Biaya $=(6)+((7)=$ Rp. 4.34 milyar } \\
\hline
\end{tabular}

Sumber: Hasil Perhitungan, 2018 


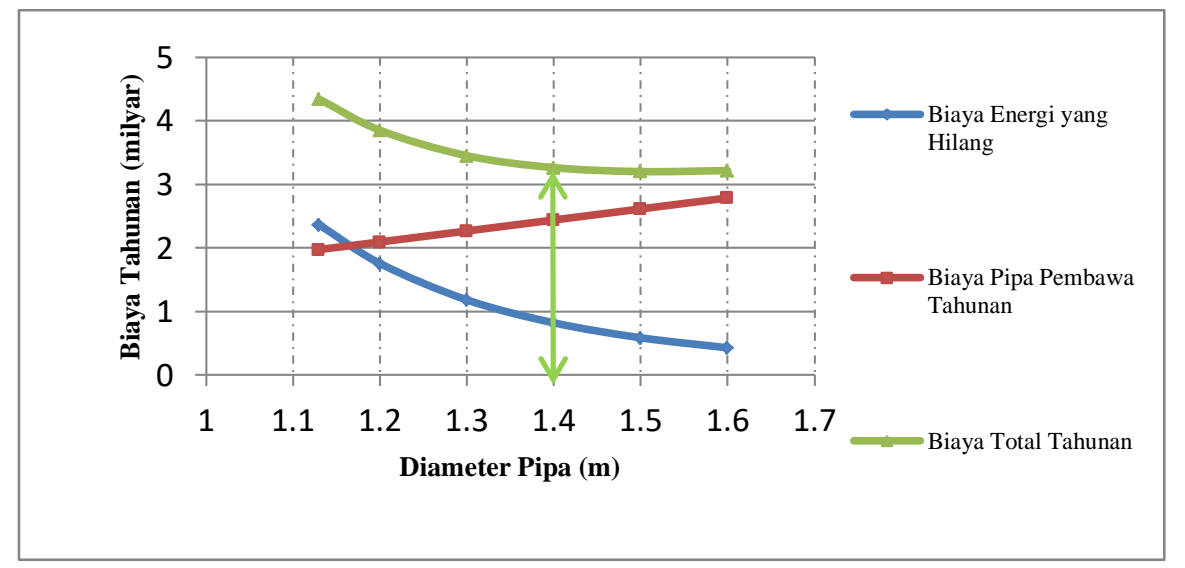

Gambar 5 Grafik Penentuan Diameter Pipa Ekonomis Skema 1 pada $\mathrm{Q}_{30}$

Tabel 3 Rekapitulasi Simulasi Energi Tahunan

\begin{tabular}{|c|c|c|c|c|c|c|c|c|}
\hline & & Debit Renc & & $\mathrm{Q}_{30}$ & $\mathrm{Q}_{35}$ & $\mathrm{Q}_{40}$ & $\mathrm{Q}_{45}$ & $\mathrm{Q}_{50}$ \\
\hline & & & & $2,49 \mathrm{~m}^{3} / \mathrm{dt}$ & $2,42 \mathrm{~m}^{3} / \mathrm{dt}$ & $2,33 \mathrm{~m}^{3} / \mathrm{dt}$ & $2,24 \mathrm{~m}^{3} / \mathrm{dt}$ & $2,10 \mathrm{~m}^{3} / \mathrm{dt}$ \\
\hline- & (1) & Energi Tahunan & GWH & 9.235 & 9.179 & 9.093 & 8.931 & 8.736 \\
\hline ש & (2) & DayaTerinstal & MW & 1.653 & 1.609 & 1.554 & 1.479 & 1.396 \\
\hline$\stackrel{D}{0}$ & (3) & Faktor Kapasitas & $\%$ & 63.84 & 65.20 & 66.85 & 68.99 & 71.51 \\
\hline & & Kelayakan & & Tidak Layak & Layak & Layak & Layak & Layak \\
\hline$N$ & (1) & Energi Tahunan & GWH & 12.620 & 12.546 & 12.432 & 12.283 & 11.917 \\
\hline 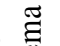 & $(2)$ & DayaTerinstal & MW & 2.249 & 2.191 & 2.118 & 2.035 & 1.897 \\
\hline$\frac{\tilde{v}}{\infty}$ & (3) & Faktor Kapasitas & $\%$ & 64.11 & 65.44 & 67.07 & 68.96 & 71.77 \\
\hline & & Kelayakan & & Tidak Layak & Layak & Layak & Layak & Layak \\
\hline$m$ & (1) & Energi Tahunan & GWH & 14.213 & 14.130 & 14.001 & 13.834 & 13.417 \\
\hline $\mathbb{\Xi}$ & $(2)$ & DayaTerinstal & MW & 2.532 & 2.466 & 2.384 & 2.291 & 2.135 \\
\hline$\overline{\underline{D}}$ & (3) & Faktor Kapasitas & $\%$ & 64.15 & 65.48 & 67.11 & 68.99 & 71.80 \\
\hline & & Kelayakan & & Tidak Layak & Layak & Layak & Layak & Layak \\
\hline$\overline{\mathrm{Ket}}$ & $n$ & & & & & & & \\
\hline (1) $\mathrm{E}$ & nergit & tahunan $=9.235 \mathrm{GWh}$ & sil simula & asi energi) & & & & \\
\hline (2) $\mathrm{D}$ & aya te & rinstal $=(2.49 * 9.81 * 0$ & $1 * 0.95 * 7$ & $78.16) / 1000=1$. & MW & & & \\
\hline 3) & stor 1 & kapasitas $=((1) /((2) * 36$ & $* 24) * 100$ & $0 \%=63.84 \%$ & & & & \\
\hline
\end{tabular}

Sumber: Hasil Perhitungan, 2018.

Tabel 4 Potensi Optimum Pada Skema 1

\begin{tabular}{|c|c|c|c|c|c|c|c|}
\hline & & \multirow{2}{*}{ Debit Rencana } & \multirow{2}{*}{$\mathrm{m}^{3} / \mathrm{dt}$} & $\mathrm{Q}_{35}$ & $\mathrm{Q}_{40}$ & $\mathrm{Q}_{45}$ & $\mathrm{Q}_{50}$ \\
\hline & & & & 2,42 & 2,33 & 2,24 & 2,10 \\
\hline \multirow{7}{*}{ 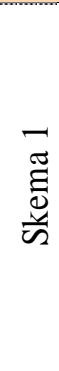 } & (1) & Panjang Pipa Pembawa & $\mathrm{m}$ & 1471 & 1471 & 1471 & 1471 \\
\hline & (2) & Diameter Pipa Pembawa & $\mathrm{m}$ & 1.5 & 1.5 & 1.4 & 1.4 \\
\hline & (3) & Energi Tahunan & GWH & 9.18 & 9.09 & 8.93 & 8.74 \\
\hline & (4) & DayaTerinstal & MW & 1.61 & 1.55 & 1.48 & 1.40 \\
\hline & (5) & Total Estimasi Biaya & Rp. Milyar & 50.48 & 50.20 & 48.54 & 48.11 \\
\hline & $(6)$ & $\begin{array}{l}\text { Biaya Tahunan }(\mathrm{i}=10 \%, \\
\mathrm{n}=30 \mathrm{thn})\end{array}$ & Rp. Milyar & 5.36 & 5.33 & 5.15 & 5.10 \\
\hline & (7) & Biaya Energi & Rp. & 583.45 & 585.67 & 576.61 & 584.20 \\
\hline
\end{tabular}

Keterangan:

(3) Energi tahunan $=9.18 \mathrm{GWh}$ (dari simulasi energi)

(4)Daya terinstal $=(2.42 * 9.81 * 0.91 * 0.95 * 78.16) / 1000=1.61 \mathrm{MW}$

(5) Total estimasi biaya $=$ Rp. 50.48 Milyar $($ RAB masing-masing skema)

(6) Biaya tahunan $=(5) * 0.10608=$ Rp. 5.36 Milyar

(7) Biaya energi $=(6) /(3)=$ Rp. 538.45

Sumber: Hasil Perhitungan, 2018. 
Tabel 5 Potensi Optimum Pada Skema 2

\begin{tabular}{|c|c|c|c|c|c|c|c|}
\hline & & \multirow{2}{*}{ Debit Rencana } & \multirow{2}{*}{$\mathrm{m}^{3} / \mathrm{dt}$} & $\mathrm{Q}_{35}$ & $\mathrm{Q}_{40}$ & $\mathrm{Q}_{45}$ & $\mathrm{Q}_{50}$ \\
\hline & & & & 2,42 & 2,33 & 2,24 & 2,10 \\
\hline \multirow{7}{*}{ 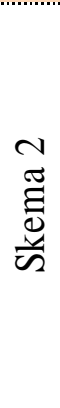 } & $(1)$ & Panjang Pipa Pembawa & $\mathrm{m}$ & 1957 & 1957 & 1957 & 1957 \\
\hline & (2) & Diameter Pipa Pembawa & $\mathrm{m}$ & 1.4 & 1.4 & 1.4 & 1.3 \\
\hline & $(3)$ & Energi Tahunan & GWH & 12.55 & 12.43 & 12.28 & 11.92 \\
\hline & (4) & Energi Terinstal & MW & 2.19 & 2.12 & 2.04 & 1.90 \\
\hline & $(5)$ & Total Estimasi Biaya & Rp. Milyar & 65.45 & 65.08 & 64.65 & 59.80 \\
\hline & $(6)$ & $\begin{array}{l}\text { Biaya Tahunan }(\mathrm{i}=10 \% \\
\mathrm{n}=30 \mathrm{thn})\end{array}$ & Rp. Milyar & 6.94 & 6.90 & 6.86 & 6.34 \\
\hline & $(7)$ & Biaya Energi & Rp. & 553.40 & 555.31 & 558.35 & 532.34 \\
\hline
\end{tabular}

Keterangan:

(3) Energi tahunan $=12.55 \mathrm{GWh}$ (dari simulasi energi)

(4)Daya terinstal $=(2.42 * 9.81 * 0.91 * 0.95 * 106.7) / 1000=2.19 \mathrm{MW}$

(5) Total estimasi biaya $=$ Rp. 65.45 Milyar (RAB masing-masing skema)

(6) Biaya tahunan $=(5) * 0.10608=$ Rp. 6.94 Milyar

(7) Biaya energi $=(6) /(3)=$ Rp. 553.40

Sumber: Hasil Perhitungan, 2018.

Tabel 6Potensi Optimum Pada Skema 3

\begin{tabular}{|c|c|c|c|c|c|c|c|}
\hline & & \multirow{2}{*}{ Debit Rencana } & \multirow{2}{*}{$\mathrm{m}^{3} / \mathrm{dt}$} & $\mathrm{Q}_{35}$ & $\mathrm{Q}_{40}$ & $\mathrm{Q}_{45}$ & $\mathrm{Q}_{50}$ \\
\hline & & & & 2,42 & 2,33 & 2,24 & 2,10 \\
\hline \multirow{7}{*}{$\begin{array}{l}m \\
\tilde{\Xi} \\
\frac{\tilde{D}}{\mathscr{N}}\end{array}$} & $(1)$ & Panjang Pipa Pembawa & $\mathrm{m}$ & 2300 & 2300 & 2300 & 2300 \\
\hline & $(1)$ & Diameter Pipa Pembawa & $\mathrm{m}$ & 1.4 & 1.4 & 1.4 & 1.3 \\
\hline & $(1)$ & Energi Tahunan & GWH & 14.13 & 14.00 & 13.83 & 13.42 \\
\hline & $(1)$ & Energi Terinstal & MW & 2.47 & 2.38 & 2.29 & 2.14 \\
\hline & $(1)$ & Total Estimasi Biaya & Rp. Milyar & 76.87 & 76.45 & 75.97 & 69.64 \\
\hline & $(1)$ & $\begin{array}{l}\text { Biaya Tahunan }(\mathrm{i}=10 \%, \\
\mathrm{n}=30 \mathrm{thn})\end{array}$ & Rp. Milyar & 8.15 & 8.11 & 8.06 & 7.39 \\
\hline & $(1)$ & Biaya Energi & $\mathrm{Rp}$. & 577.09 & 579.21 & 582.53 & 550.59 \\
\hline \multicolumn{8}{|c|}{ Keterangan: } \\
\hline \multicolumn{8}{|c|}{ (3) Energi tahunan = $14.13 \mathrm{GWh}$ (dari simulasi energi) } \\
\hline \multicolumn{8}{|c|}{ (4) Daya terinstal $=(2.42 * 9.81 * 0.91 * 0.95 * 119.14) / 1000=2.47 \mathrm{MW}$} \\
\hline \multicolumn{8}{|c|}{ (5) Total estimasi biaya $=$ Rp. 76.87 Milyar (RAB masing-masing skema) } \\
\hline \multicolumn{8}{|c|}{ (6) Biaya tahunan $=(5) * 0.10608=$ Rp. 8.15 Milyar } \\
\hline \multicolumn{8}{|c|}{ (7) Biaya energi $=(6) /(3)=$ Rp. 577.09} \\
\hline
\end{tabular}

Sumber: Hasil Perhitungan, 2018.

Sehingga dari keseluruhan skema dan beberapa pilihan debit yang telah ditentukan paling optimum didapatkan rekapitulasi sebagai berikut : 
Tabel 7 Rakapitulasi Pengembangan Potensi Optimum

\begin{tabular}{c|l|c|c|c|c}
\hline No & \multicolumn{2}{|c|}{ Skema } & 1 & 2 & 3 \\
\hline \multirow{2}{*}{1} & \multirow{2}{*}{ Debit Rencana } & \multirow{2}{*}{$\mathrm{m}^{3} / \mathrm{dt}$} & $\mathrm{Q}_{45}$ & $\mathrm{Q}_{50}$ & $\mathrm{Q}_{50}$ \\
\cline { 4 - 6 } & & 2,24 & 2,10 & 2,10 \\
\hline 2 & Tinggi Jatuh & $\mathrm{m}$ & 80,1 & 110,1 & 124,1 \\
\hline 3 & Panjang Pipa & $\mathrm{m}$ & 1471 & 1957 & 2300 \\
\hline 4 & Diameter Pipa & $\mathrm{m}$ & 1,4 & 1,3 & 1,3 \\
\hline 5 & Energi Terinstal & $\mathrm{MW}$ & 1,48 & 1,90 & 2,14 \\
\hline 6 & Energi Tahunan & $\mathrm{GWH}$ & 8,93 & 11,92 & 13,42 \\
\hline 7 & Faktor Kapasitas & $\%$ & 68,99 & 71,77 & 71,80 \\
\hline \hline 8 & Biaya Energi & $\mathrm{Rp}$. & 576,6 & 532,3 & 550,6 \\
\hline
\end{tabular}

Sumber: Hasil Perhitungan, 2018.

Pada

Tabel 7 Rakapitulasi Pengembangan Potensi Optimum terlihat bahwa skema yang paling optimum adalah skema 2 dengan debit rencana $\mathrm{Q}_{50}$, diameter pipa 1,3 meter, dan energi terinstal $2 \times 0,95 \mathrm{MW}$ dengan turbin francis dan biaya energi sebesar Rp. 532,3.

\section{PENUTUP}

Kesimpulan

Sesuai dengan rumusan masalah pada studi Kajian Optimasi Pembangkit Tenaga Mikro Hidro Rantau Suli di Kabupaten Merangin, Provinsi Jambi. Maka dapat diambil kesimpulan adalah sebagai berikut:

1. Hasil FDC merupakan bangkitan debit dari data stasiun hujan Keliling Danau dari tahun 2007 sampai dengan tahun 2016 dengan menggunakan metode F.J. Mock yang memiliki koefisien runoff sebesar 0,57. Sedangkan debit yang dipakai pada perencanaan adalah debit $\mathrm{Q}_{30}=2,49 \mathrm{~m}^{3} / \mathrm{dt}, \mathrm{Q}_{35}=2,42 \mathrm{~m}^{3} / \mathrm{dt}, \mathrm{Q}_{40}=$ $2,33 \mathrm{~m}^{3} / \mathrm{dt}, \mathrm{Q}_{45}=2,24 \mathrm{~m}^{3} / \mathrm{dt}$ dan $\mathrm{Q}_{50}=$ $2,11 \mathrm{~m}^{3} / \mathrm{dt}$.

2. Pada studi ini direncanakan terdapat tiga buah potensial skema pipa pembawa yaitu untuk skema 1 memiliki tinggi jatuh setinggi 80,1 meter dan panjang pipa pembawa sepanjang 1471 meter, untuk skema 2 memiliki tinggi jatuh setinggi 110,1 meter dan panjang pipa pembawa sepanjang 1957 meter, dan skema 3 memiliki tinggi jatuh setinggi 124,1 meter dan panjang pipa pembawa se-panjang 2300 meter.

3. Pada analisa diameter pipa pem-bawa menghasilkan optimasi diameter untuk masing - masing skema adalah berbeda - beda, seperti berikut :

a. Pada skema 1

Untuk $\mathrm{Q}_{30}, \mathrm{Q}_{35}$,dan $\mathrm{Q}_{40}$ diperoleh diameter optimum $=1,5$ meter, Sedangkan untuk $\mathrm{Q}_{45}$ dan $\mathrm{Q}_{50}$ diperoleh diameter optimum $=1,4$

b. Pada skema 2

Untuk $\mathrm{Q}_{30}, \mathrm{Q}_{35}, \mathrm{Q}_{40}$, dan $\mathrm{Q}_{45}$ diperoleh diameter optimum $=1,4$ meter, Sedangkan untuk $\mathrm{Q}_{50}$ diperoleh diameter optimum $=1,3$

c. Pada skema 3

Untuk $\mathrm{Q}_{30}, \mathrm{Q}_{35}, \mathrm{Q}_{40}$, dan $\mathrm{Q}_{45}$ diperoleh diameter optimum $=1,4$ meter, Sedangkan untuk $\mathrm{Q}_{50}$ diperoleh diameter optimum $=1,34$.

4. Pemilihan turbin dilakukan dengan menggunakan diagram turbin yang meng-hubungkan tinggi jatuh dari masing-masing skema dan debit rencananya. Pada studi ini didapatkan ketiga skema berada pada wilayah 
turbin Francis dan turbin Kaplan. Akan tetapi turbin Francis memiliki putaran yang lebih tinggi daripada turgo, sehingga ukuran generator francis lebih kecil daripada turgo yang berakibat pada harga jualnya. Selain itu francis memiliki efisiensi yang lebih baik daripada turgo sehingga tidak banyak energi yang terbuang. Sehingga dipilih turbin Francis sebagai turbin yang paling optimal pada studi ini.

5. Energi optimal didapatkan dengan cara membandingkan biaya energi dari semua skema, dimana biaya energi yang terkecil yang dapat menghasilkan keuntungan yang paling tinggi. Sehingga didapatkan skema yang paling optimum adalah skema 2 yang memiliki tinggi jatuh 110,1 meter, panjang pipa pembawa 1957 meter, dengan debit rencana $\mathrm{Q}_{50}$, ber-diameter pipa pembawa 1,3 meter, energi terinstal $2 \mathrm{x}$ 0,95 MW dengan turbin Francis dan biaya energi sebesar Rp. 532,3. Sehingga pada skema ini meng-hasilkan nilai NPV selama perhitungan 30 tahun adalah Rp 20.872.725.735.-, nilai IRR sebesar $14,46 \%$, dan $\mathrm{B} / \mathrm{C}$ ratio 1,358.

\section{Saran}

Studi ini dirasa sudah cukup baik menggambarkan bagaimana proses optimasi dan pemilihan skema dapat dilakukan. Akan tetapi sungguh sangat baik lagi apabila terdapat studi lebih lanjut mengenai analisa Flow Duration Curve pada daerah subDAS yang tidak terukur debitnya. Dikarenakan sangat penting bagaimana kita menentukan bentuk diagram FDC, yang sangat besar pengaruhnya terhadap karakteristik turbin dan selanjutnya berdampak pada analisa energi tahunan.

\section{DAFTAR PUSTAKA}

Anonim, 2015.Jambi Dalam Angka 2015, Badan Pusat Statistik Provinsi Jambi.

Anonim, 2013.Kajian Supply and Demand Energi Kementeri Energi dan Sumber Daya Mineral Republik Indonesia.

Anonim, 2017.Peraturan Menteri Energi dan Sumber Daya Mineral Republik Indonesia Nomor 12 tentang Pemanfaatan Energi Terbarukan untuk Penyediaan Tenaga Listrik.

Pasalli and Rehiara, 2013. Design Planning of Micro-hydro Power Plant in Hink River. 4th International Conference on Sustainable Future for Human Security: Elsevier.

Tanbhir, Nawshad, Islam, IbneaSina, Syfullah, Rahman, 2011. Micro Hydro Power: Promising Solution for Off-grid Renewable Energy SourceInternational Journal of Scientific \& Engineering Research.

Vogel and Fennessey, 1995.FlowDuration Curve II: A Reviewof Applicationin Water Resources Planning. Water Resources Bulletin, Vol. 31, No.6, American Water Resources Assosiation.

Younis and Hasan, 2014.Prediction of Flow Duration Curve for Seasonal Rivers in Iraq.Jordan Journal of Civil Engineering, Volume 8, No. 1. 